〔J. Appl. Glycosci., Vol. 46, No.1, p. 15-21 (1999)〕

\title{
Raw Starch-Digesting Glucoamylase Production of Rhizopus sp. MKU 40 Using a Metal-Ion Regulated Liquid Medium
}

\author{
Hiroshi Morita, Kouhei Mizuno, Mayumi Matsunaga and Yusaku Fujio* \\ Department of Food Science and Technology, Faculty of Agriculture, Kyushu University \\ (6-10-1, Hakozaki, Higashi-ku, Fukuoka 812-8581, Japan)
}

\begin{abstract}
In this study we attempted to control some spécified metal-ion concentrations in a liquid medium and found a highly raw starch-digesting glucoamylase (RSDG) producing culture with protease-less activity, which we have called a metal-ion regulated liquid medium. Rhizopus sp. MKU 40 could not grow and produce glucoamylase (GA) in the liquid medium without metal ions (SLS medium). The addition of iron, magnesium, and zinc ions in the liquid medium was essential to growth and GA production of Rhizopus sp: MKU 40. Calcium ions also stimulated its growth and GA production. To summarize, the addition of $75 \mathrm{ppm}$ calcium ions, $2 \mathrm{ppm}$ iron ions, $49 \mathrm{ppm}$ magnesium ions, and $0.7 \mathrm{ppm}$ zinc ion to the SLS liquid medium was the best condition for producing GA and resulted in a high specific activity of GA (21.9 U/mg protein). Specific RSDG activity of the crude enzyme was $5.7 \mathrm{U} /$ $\mathrm{mg}$ protein, and the ratio of RSDG activity to GA activity was 0.26 . Since the purification was easy, the purification of GA was done in only two steps (ammonium sulfate precipitation and column chromatography on CM-Sephadex C-50). The enzyme was purified about 4.8 -fold based on specific GA activity with an $86.0 \%$ yield based on 'GA activity from culture supernatant. The enzyme was proved to be homogeneous as judged by SDS-PAGE, and it has a molecular mass of about $80.4 \mathrm{kDa}$ by comparison of its relative mobility on SDS-PAGE with those of standard proteins. For purified enzymes, the ratio of RSDG activity to GA activity was 0.16 .
\end{abstract}

Mycelium glucoamylase [GA, EC 3.2.1.3], which often exists in multiple forms, can be classified as GA-I and GA-II. GA-I, which can adsorb raw starches, shows high raw starchdigesting glucoamylase (RSDG) activity. GAII, which can not adsorb raw starches, shows extremely weak RSDG activity. ${ }^{1-3)}$ GA-I is a commercially important enzyme to the food and alcohol industries. It has the potential for producing glucose from raw starchy materials and it is beneficial from the viewpoint of saving energy. However, the presence of a high protease activity in the culture leads to the production of GA-II from GA-I; RSDG activity in the culture also decreases. ${ }^{4)}$

In the previous paper, ${ }^{5,6)}$ we selected Rhizopus sp. A-11 isolated from ragi. Ragi, an Indonesian tempeh starter, is made with rice flour and contains yeast, bacteria, and fungi. We

\footnotetext{
${ }^{*}$ Corresponding author.
}

attempted to control some specified metal-ion concentrations in a liquid medium and achieved a high level of GA production in a so-called metal-ion regulated liquid medium. We achieved substantial results as the GA activity reached $3.94 \mathrm{U} / \mathrm{mL}$ under $2 \mathrm{ppm}$ of 'iron ion" stress, $49 \mathrm{ppm}$ of magnesium ion stress, $0.7 \mathrm{ppm}$ of zinc ion stress, and $75 \mathrm{ppm}$ of calcium ion stress in a jar fermentor. Specific GA activity was $22.4 \mathrm{U} / \mathrm{mg}$ protein, which is superior to that of a wheat bran solid medium (Elegado's medium $^{7)}$ ). We characterized the GA from Rhizopus sp. A-11 and found that the GA had a strong RSDG activity.

In this paper, we selected Rhizopus sp. MKU 40 because this strain showed the highest GA and RSDG activity, as well as Rhizopus sp. A-11, among the 45 strains of Rhizopus tested. We investigated the effects of various metal-ions supplementation on GA and RSDG production. We also improved a liquid culture system for 
GA and RSDG production, using a metal-ion regulated liquid medium.

\section{MATERIAL AND METHODS}

Microorganisms. Rhizopus sp. MKU 40 was provided by Kasetsart University, Department of Microbiology, Thailand. Among 45 Rhizopus strains tested, MKU 40 was selected as the best producer of GA and RSDG, and we used it in the following experiments.

Metal ions. The metal compounds tested were silver sulfate $\left(\mathrm{Ag}^{+}\right)$, copper sulfate $\left(\mathrm{Cu}^{2+}\right)$, nickel chloride hexahydrate $\left(\mathrm{Ni}^{2+}\right)$, iron sulfate heptahydrate $\left(\mathrm{Fe}^{2+}\right)$, manganese sulfate pentahydrate $\left(\mathrm{Mn}^{2+}\right)$, calcium chloride $\left(\mathrm{Ca}^{2+}\right)$, lead acetate trihydrate $\left(\mathrm{Pb}^{2+}\right)$, cobalt chloride hexahydrate $\left(\mathrm{Co}^{2+}\right)$, zinc sulfate heptahydrate $\left(\mathrm{Zn}^{2+}\right)$, magnesium sulfate heptahydrate $\left(\mathrm{Mg}^{2+}\right)$, aluminum chloride hexahydrate $\left(\mathrm{Al}^{3+}\right)$, and sodium molybdate dihydrate $\left(\mathrm{Mo}^{6+}\right)$.

Cultivation. The basal liquid medium (SLS medium) consisted of $1 \mathrm{~g}$ of liquefied cassava starch, $0.4 \mathrm{~g}$ of ammonium acetate, $0.1 \mathrm{~g}$ of dipotassium hydrogenphosphate, and $0.33 \mathrm{~g}$ of citric acid dissolved in $100 \mathrm{~mL}$ of deionized water. The $\mathrm{pH}$ was adjusted to 6.0 with sodium hydroxide. The medium was sterilized at $121^{\circ} \mathrm{C}$ for $20 \mathrm{~min}$ in a shaking flask. The Rhizopus mycelia and spores were precultured on a slant of potato dextrose agar at $30^{\circ} \mathrm{C}$ for 7 days. Two milliliters of the spore and the mycelia suspension (about $10^{9} \mathrm{cfu}$ per $\mathrm{mL}$ ) were inoculated into the shaking flask. The culture was incubated at $30^{\circ} \mathrm{C}$ for 2 days on a reciprocal shaker with agitation at 300 strokes per min. The liquid culture was also used in a jar fermentor (5 L with a 2-L working volume). Forty milliliters of the spore and the mycelia suspension (about $10^{9} \mathrm{cfu}$ per $\mathrm{mL}$ ) were inoculated into the jar fermentor (Iwashiya BioScience Co., Ltd.). Cultivation was carried out at $30^{\circ} \mathrm{C}$ for $30 \mathrm{~h}$ with an agitation of $600 \mathrm{rpm}$ and an aeration rate of $1 \mathrm{vvm}$.

Preparation of the enzyme solution. The culture liquid was filtered through a filter paper (No.7, Toyo Roshi Ltd.) to remove the mycelia. The filtrate was used as a crude enzyme solution.
Determination of dry mycelial weight (DMW). The DMW was determined after drying of the mycelia in a $105^{\circ} \mathrm{C}$ oven for $24 \mathrm{~h}$. DMW was defined as mycelial weight per $100 \mathrm{~mL}$ of culture medium.

Determination of GA activity. The reaction mixture for the GA assay was composed of $1 \mathrm{~mL}$ of $2 \%(\mathrm{w} / \mathrm{v})$ soluble starch (Nacalai Tesque Co.) solution in a $0.1 \mathrm{M}$ acetate buffer ( $\mathrm{pH} 4.5)$, and $1 \mathrm{~mL}$ of enzyme solution. The reaction was carried out at $40^{\circ} \mathrm{C}$ for $20 \mathrm{~min}$. It was stopped by heating the test tubes in a boiling-water bath for $5 \mathrm{~min}$. The amount of liberating glucose was determined by the glucose oxidase (GOD) method..8) One unit of GA activity was defined as one $\mu$ mol of liberated glucose per min per $\mathrm{mL}$ enzyme solution.

Determination of RSDG activity. The reaction mixture for the determination of raw starch digestion contained $2.5 \mathrm{~mL}$ of a. $2 \%$ (w/ v) raw cornstarch (Nacalai Tesque Co.) suspension in a $0.1 \mathrm{M}$ acetate buffer ( $\mathrm{pH} 4.5)$, and $2.5 \mathrm{~mL}$ of a diluted enzyme solution. The reaction mixture, contained in a L-test tube, was incubated at $40^{\circ} \mathrm{C}$ for $60 \mathrm{~min}$. The amount of liberating glucose was measured by the GOD method.8) One unit of RSDG activity was defined as one $\mu \mathrm{mol}$ of liberated glucose per min per $\mathrm{mL}$ enzyme solution.

Determination of protein. Protein was measured by using the method of Bradford ${ }^{9)}$ with reagents from Bio-Rad; bovine serum albumin was the standard.

Purification of GA. The procedure for the purification of GA from crude enzymes was as follows, and all operations were done at $4^{\circ} \mathrm{C}$.

\section{Step 1. Ammonium sulfate precipitation}

One liter of the culture filtrate was fractionated by adding solid ammonium sulfate to $80 \%$ saturation. The precipitate was collected by centrifugation at $12,000 \mathrm{rpm}$ for $20 \mathrm{~min}$. It was dissolved in $20 \mathrm{~mL}$ of deionized water and dialyzed against a $0.05 \mathrm{M}$ acetate buffer $(\mathrm{pH}$ 4.0) overnight. The dialyzed enzyme solution was centrifuged at $12,000 \mathrm{rpm}$ for $20 \mathrm{~min}$. The supernatant was filtrated through a $0.45 \mu \mathrm{m}$ membrane filter and concentrated by ultrafiltration with a UK-10 ultrafilter (Toyo Roshi Ltd.) to about $10 \mathrm{~mL}$. 
Step 2. Column chromatography on CM. Sephadex C-50

About $10 \mathrm{~mL}$ of the sample from Step 1 was put on a CM-Sephadex column $2.6 \times 45 \mathrm{~cm}$ equilibrated with a $0.05 \mathrm{M}$ acetate buffer $(\mathrm{pH}$ 4.0) for $24 \mathrm{~h}$. The enzyme was eluted with the buffer, making a linear gradient from $0 \mathrm{M}$ to $0.6 \mathrm{M}$ of sodium chloride. The flow rate was 20 $\mathrm{mL} / \mathrm{h}$, and the eluent was collected in $10 \mathrm{~mL}$ fractions. The GA active fractions were then collected and designated as purified GA.

Electrophoresis. Sodium dodecylsulfate polyacrylamide gel electrophoresis (SDS-PAGE) was performed by using the method of Laemmli ${ }^{10)}$ with a $12.5 \%$ polyacrylamide gel containing $0.1 \%$ SDS and 5\% 2-mercaptoethanol. The gels were stained with Quick-CBB (Wako Chemicals Co., Ltd.). The standard proteins used (Pharmacia Biotech Ltd.) were phosphorylase $b(94 \mathrm{kDa})$, bovine serum albumin $(68 \mathrm{kDa})$, ovalbumin $(43 \mathrm{kDa})$, carbonic anhydrase $(30 \mathrm{kDa})$, soybean trypsin inhibitor $(20.1 \mathrm{kDa})$, and $\alpha$-lactalbumin $(14.4 \mathrm{kDa})$.

Determination of raw starch adsorption. The enzyme solution was diluted such that it had a GA activity of a $0.94 \mathrm{U} / \mathrm{mL}$ in a $0.1 \mathrm{M}$ acetate buffer ( $\mathrm{pH}$ 4.5). One gram of raw cornstarch was added to $5 \mathrm{~mL}$ of the diluted enzyme solution and placed for $20 \mathrm{~min}$ at $4^{\circ} \mathrm{C}$. . After centrifugation, the GA activity of the supernatant was assayed and compared with the original GA activity (in the soluble starch). The adsorption rate $(A R)$ is defined according to the following equation:

$$
A R(\%)=[(O-R) / O] \times 100
$$

where $R$ indicates the residual GA activity in the supernatant and $O$ indicates that of the original enzyme solution.

Determination of neutral protease activity. A modified Kunitz's method ${ }^{11)}$ was used. One milliliter of casein suspension $(2 \%[\mathrm{w} / \mathrm{v}]$ in a $0.1 \mathrm{M}$ phosphate buffer [pH 6.8]) and $1 \mathrm{~mL}$ of enzyme solution were mixed and incubated at $40^{\circ} \mathrm{C}$ for $30 \mathrm{~min}$. The reaction was stopped by adding $10 \mathrm{~mL}$ of $5 \%(\mathrm{w} / \mathrm{v})$ trichloroacetic acid. After standing for $60 \mathrm{~min}$ at room temperature, the precipitate of the unhydrolyzed casein was removed by filtration, and an absorbance of 280 $\mathrm{nm}$ of the filtrate was measured. One unit of neutral protease was defined as one $\mu \mathrm{mol}$ of liberated tyrosine per min per $\mathrm{mL}$ enzyme solution.

Determination of acid protease activity. A modified Anson-hemoglobin method ${ }^{12)}$ was used. Two-and-one-half milliliters of a hemoglobin solution $(0.6 \%[\mathrm{w} / \mathrm{v}]$ in a $0.05 \mathrm{M}$ acetate buffer [pH 4.5]) and $1 \mathrm{~mL}$ of an enzyme solution were mixed and incubated at $40^{\circ} \mathrm{C}$ for $30 \mathrm{~min}$. The reaction was stopped by adding $5 \mathrm{ml}$ of $5 \%$ trichloroacetic acid. After standing for $60 \mathrm{~min}$ at $40^{\circ} \mathrm{C}$, the unhydrolyzed hemoglobin precipitate was removed by filtration, and an absorbance of $280 \mathrm{~nm}$ of the filtrate was measured. One unit of acid protease was defined as one $\mu$ mol liberated tyrosine per $\min$ per $\mathrm{mL}$ enzyme solution.

Determination of $\alpha$-amylase activity. A modified Fuwa's method $^{13}$ was used. The reaction mixture was composed of $1 \mathrm{~mL}$ of $2 \%$ (w/v) soluble starch (Nacalai Tesque Co.) solution in a $0.1 \mathrm{M}$ acetate buffer ( $\mathrm{pH} 4.5)$, and $1 \mathrm{~mL}$ of enzyme solution. The reaction was carried out at $40^{\circ} \mathrm{C}$ for $30 \mathrm{~min}$. It was stopped by the addition of $3 \mathrm{~mL}$ of $1 \mathrm{~N}$ acetic acid. A $0.2 \%(\mathrm{w} / \mathrm{v})$ iodine solution containing $2 \%(\mathrm{w} /$ $\mathrm{v}$ ). potassium iodine was added to the reaction mixture, and an absorbance of $700 \mathrm{~nm}$ was measured. One unit of $\alpha$-amylase activity was defined as the amount of $\alpha$-amylase which decrease $10 \%$ in absorbance at $700 \mathrm{~nm}$.

\section{RESULTS}

Supplementation of iron, magnesium, and zinc ions in combination.

Table 1 shows the effects of iron, magnesium, and zinc ions supplementation on GA activity, RSDG activity, and DMW of Rhizopus sp. MKU 40. A basal medium was the SLS medium. Rhizopus sp. MKU 40 did not grow or produce GA and RSDG in the SLS medium (no metal ions supplemented). Neither did the addition of two of these ions to the SLS medium in combination stimulate GA and RSDG production. Adding all three ions to the basal medium made for better GA and RSDG production than any combination of two of the three metal ions did. 
Table 1. Effects of $\mathrm{Fe}^{2+}, \mathrm{Mg}^{2+}$, and $\mathrm{Zn}^{2+}$ supplementation on GA activity, RSDG activity, and DMW of Rhizopus sp. MKU40.

\begin{tabular}{lccc}
\hline Combination & $\begin{array}{c}\text { GA } \\
\text { activity } \\
(\mathrm{U} / \mathrm{mL})\end{array}$ & $\begin{array}{c}\text { RSDG } \\
\text { activity } \\
(\mathrm{U} / \mathrm{mL})\end{array}$ & $\begin{array}{c}\mathrm{DMW} \\
(\mathrm{g} / 100 \mathrm{~mL})\end{array}$ \\
\hline $\mathrm{SLS}$ medium & 0 & 0 & 0.01 \\
$\mathrm{SLS}+\mathrm{Fe}^{a}$ & 0 & 0 & 0.03 \\
$\mathrm{SLS}+\mathrm{Mg}^{b}$ & 0 & 0 & 0.05 \\
$\mathrm{SLS}+\mathrm{Zn}^{c}$ & 0 & 0 & 0.04 \\
$\mathrm{SLS}+\mathrm{Fe}+\mathrm{Mg}$ & 0.11 & 0 & 0.08 \\
$\mathrm{SLS}+\mathrm{Fe}+\mathrm{Zn}$ & 0.06 & 0 & 0.08 \\
$\mathrm{SLS}+\mathrm{Mg}+\mathrm{Zn}$ & 0.61 & 0.14 & 0.18 \\
$\mathrm{SLS}+\mathrm{Zn}+\mathrm{Mg}+\mathrm{Fe}$ & 2.72 & 0.67 & 0.34 \\
\hline
\end{tabular}

${ }^{a} \mathrm{FeSO}_{4}: 7 \mathrm{H}_{2} \mathrm{O} 0.01 \mathrm{~g} / \mathrm{L}\left(\mathrm{Fe}^{2+}, 2 \mathrm{ppm}\right),{ }^{b} \mathrm{MgSO}_{4} \cdot 7 \mathrm{H}_{2} \mathrm{O} \quad 0.5$ $\mathrm{g} / \mathrm{L}\left(\mathrm{Mg}^{2+}, 49 \mathrm{ppm}\right),{ }^{c} \mathrm{ZnSO}_{4} \cdot 7 \mathrm{H}_{2} \mathrm{O} 0.003 \mathrm{~g} / \mathrm{L}\left(\mathrm{Zn}^{2+}, 0.7\right.$ $\mathrm{ppm})$.
The optimum concentrations of iron, magnesium, and zinc ions for GA and RSDG production.

Figure 1 shows the optimum concentrations of iron, magnesium, and zinc ions for GA and RSDG production of Rhizopus sp. MKU 40. The addition of iron, magnesium, and zinc ions to the SLS medium was essential to growth and to GA and RSDG production. The maximum GA and RSDG activity was obtained for $2 \mathrm{ppm}$ of iron ions, $49 \mathrm{ppm}$ of magnesium ions and 0.7 ppm of zinc ion:

Supplementation of other metal ions for $G A$ production.

Table 2 shows the effects of other metal-ion

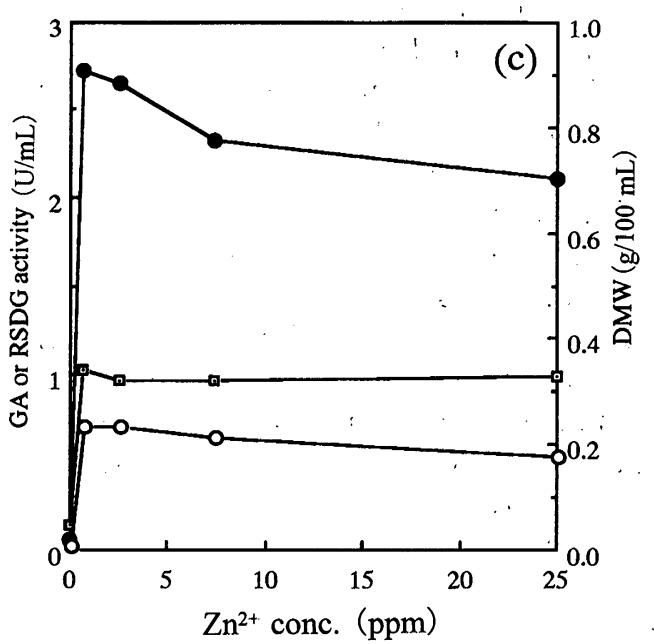

Fig. 1. The optimum concentrations of (a) iron, (b) magnesium, and (c) zinc ions for GA and RSDG production of Rhizopus sp. MKU 40.

The basal medium was (a) SLS medium supplemented with $49 \mathrm{ppm} \mathrm{Mg}^{2+}$ and $0.7 \mathrm{ppm}$ $\mathrm{Zn}^{2+}$, (b) SLS medium supplemented with $2 \mathrm{ppm}$ $\mathrm{Fe}^{2+}$ and $0.7 \mathrm{ppm} \mathrm{Zn}^{2+}$, and (c) SLS medium supplemented with 2 ppm $\mathrm{Fe}^{2+}$ and $49 \mathrm{ppm} \mathrm{Mg}^{2+}$. The shaking cultivation was performed at $30^{\circ} \mathrm{C}$ for 2 days. GA activity; $\bigcirc$, RSDG activity; $\bullet$, DMW. 
Table 2. Effects of other metal ions supplementation on GA activity of Rhizopus sp. MKU40.

\begin{tabular}{ccrrr}
\hline & \multicolumn{4}{c}{ Relative activity $^{a}(\%)$} \\
\cline { 2 - 5 } Metal ion & \multicolumn{4}{c}{ Concentration $(\mathrm{ppm})$} \\
\cline { 2 - 5 } & 0 & 1 & 10 & \multicolumn{1}{c}{50} \\
\hline $\mathrm{Ag}^{+}$ & 100 & 0 & 0 & 0 \\
$\mathrm{Cu}^{2+}$ & 100 & 75 & 34 & 35 \\
$\mathrm{Ni}^{2+}$ & 100 & 111 & 108 & 105 \\
$\mathrm{Mn}^{2+}$ & 100 & 101 & 105 & 103 \\
$\mathrm{Cd}^{2+}$ & 100 & 68 & 0 & 0 \\
$\mathrm{Ca}^{2+}$ & 100 & 100 & 101 & 117 \\
$\mathrm{~Pb}^{2+}$ & 100 & 102 & 79 & 44 \\
$\mathrm{Co}^{2+}$ & 100 & 97 & 91 & 87 \\
$\mathrm{Al}^{3+}$ & 100 & 98 & 102 & 75 \\
$\mathrm{Mo}^{6+}$ & 100 & 109 & 111 & 100 \\
\hline
\end{tabular}

${ }^{a}$ Relative activity was compared with a control medium consisting of SLS medium supplemented with $2 \mathrm{ppm} \mathrm{Fe}^{2+}, 49 \mathrm{ppm} \mathrm{Mg}^{2+}$, and $0.7 \mathrm{ppm} \mathrm{Zn}^{2+}$.

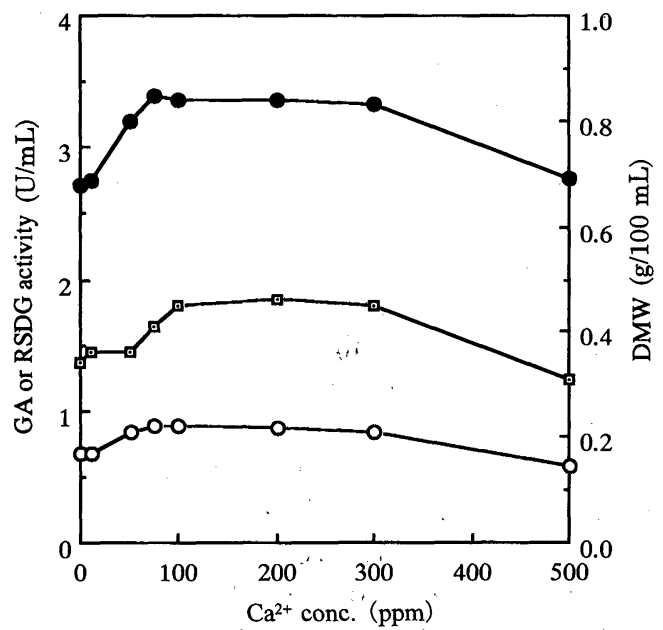

Fig. 2. The optimum concentrations of calcium irons for GA and RSDG production of Rhizopus sp. MKU 40.

The basal medium was SLS medium supplemented with 2 ppm $\mathrm{Fe}^{2+}, 49 \mathrm{ppm} \mathrm{Mg}^{2+}$, and $0.7 \mathrm{ppm} \mathrm{Zn}^{2+}$. The shaking cultivation was performed at $30^{\circ} \mathrm{C}$ for 2 days. - GA activity; $\bigcirc$, RSDG activity; $\bullet, \mathrm{DMW}$.

supplementation on the GA production of Rhizopus sp. MKU 40 when the SLS medium supplemented with $2 \mathrm{ppm}$ of iron ions, $49 \mathrm{ppm}$ of magnesium ions, and $0.7 \mathrm{ppm}$ of zinc ion were used. Of the 10 metal ions tested, the calcium ions exerted the greatest effect on GA production. Figure 2 shows the optimum concentra-

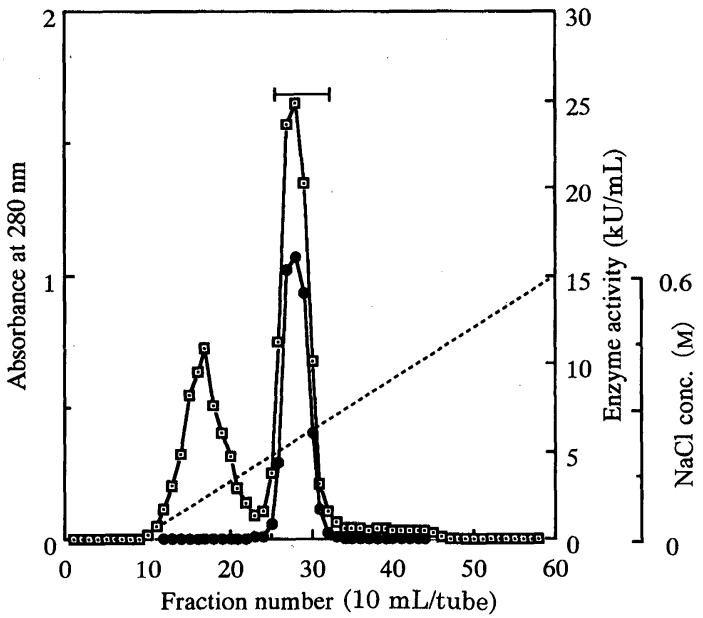

Fig. 3. CM-Sephadex C-50 ion-exchange chromatography of the enzyme sample obtained from $\left(\mathrm{NH}_{4}\right)_{2} \mathrm{SO}_{4}$ precipitation.

Flow rate was $20 \mathrm{~mL} / \mathrm{h}$. ๑, Absorbance at $280 \mathrm{~nm}$; , $\mathrm{GA}$ activity; $\cdots, \mathrm{NaCl}$ conc.

tion of calcium ions for GA and RSDG production. The supplementation of calcium ions stimulated growth and GA production of Rhizopus sp. MKU 40. The addition of $75 \mathrm{ppm}$ of calcium ions seemed to be an optimum concentration to produce GA and RSDG; and this resulted in GA and RSDG activity of 3.39 $\mathrm{U} / \mathrm{mL}$ and $0.89 \mathrm{U} / \mathrm{mL}$, respectively.

\section{Purification of $G A$.}

GA from Rhizopus sp. MKU 40 was purified by ammonium sulfate precipitation and column chromatography on CM-Sephadex C-50. The elution pattern of column chromatography on CM-Sephadex C-50 was shown in Fig. 3. The fractions of test tubes (Nos. 25-33) were collected and designated as purified GA. Table 3 summarizes the data for the purification steps of the GA. In this purification, the enzyme was purified about 4.8 -fold based on specific GA activity with an $86.0 \%$ yield based on GA activity from culture supernatant.

Purity and molecular mass of the purified enzyme.

The purified enzyme gave a single protein band on SDS-PAGE. The molecular mass of the purified enzyme was found to be about 80.4 
Table 3. A summary of the glucoamylase purification using a metal-ion regulated liquid medium ${ }^{a}$ for Rhizopus sp. MKU40 in a jar fermentor.

\begin{tabular}{lccccc}
\hline Step & $\begin{array}{c}\text { Total protein } \\
(\mathrm{mg})\end{array}$ & $\begin{array}{c}\text { Total activity } \\
(\mathrm{U})\end{array}$ & $\begin{array}{c}\text { Specific activity } \\
(\mathrm{U} / \mathrm{mg})\end{array}$ & $\begin{array}{c}\text { Purification } \\
(\text {-fold })\end{array}$ & $\begin{array}{c}\text { Yield } \\
(\%)\end{array}$ \\
\hline 1. Culture supernatant ${ }^{b}$ & 180 & 3940 & 21.9 & 1 & 100 \\
2. $\quad\left(\mathrm{NH}_{4}\right)_{2} \mathrm{SO}_{4}$ precipitation & 51 & 3740 & 73.3 & 3.3 & 94.8 \\
3. $\quad \begin{array}{c}\text { CM-Sephadex C-50 } \\
\text { chromatography }\end{array}$ & 32 & 3390 & 106.0 & 4.8 & 86.0 \\
\hline
\end{tabular}

${ }^{a}$ The basal medium was SLS medium supplemented with $2 \mathrm{ppm} \mathrm{Fe}{ }^{2+}, 49 \mathrm{ppm} \mathrm{Mg}^{2+}, 0.7 \mathrm{ppm} \mathrm{Zn}^{2+}$, and

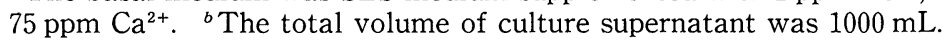

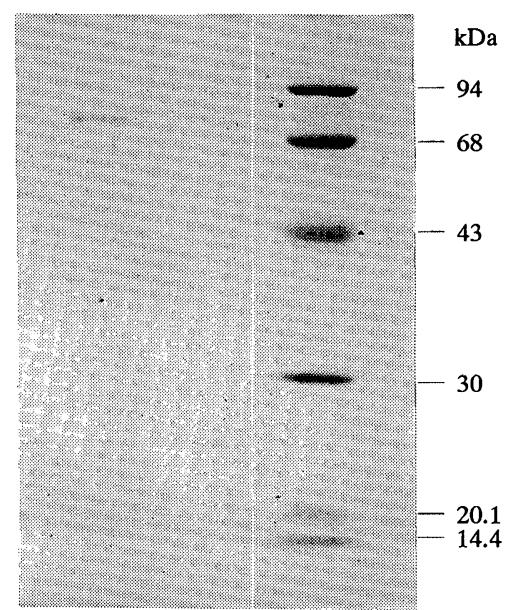

A B

Fig. 4. SDS-PAGE of the purified glucoamylase from Rhizopus sp. MKU 40.

Electrophoresis was done with molecular-mass protein standards (See Materials and Methods). Lane A, purified glucoamylase; $\mathrm{B}$, marker proteins.

$\mathrm{kDa}$ by comparison of its relative mobility on SDS-PAGE with those of standard proteins (Fig. 4).

Analysis of the crude and purified GA.

The crude and purified GA from Rhizopus sp. MKU 40 in a jar fermentor was analyzed. Based on the GA activity, the adsorption rates of the crude and purified GA on raw starch were both $100 \%$. Specific GA and RSDG activity of the crude enzyme was $21.9 \mathrm{U} / \mathrm{mg}$ protein and $5.7 \mathrm{U} / \mathrm{mg}$ protein, respectively. The ratio of RSDG activity to GA activity was 0.26 . For purified enzymes, the ratio of RSDG activity to GA activity was 0.16 . Rhizopus sp. MKU 40 produced little acid or neutral protease. The culture supernatant contained 10 $\mathrm{U} / \mathrm{mL}$ of $\alpha$-amylase activity.

\section{DISCUSSION}

Nishise et al. ${ }^{14)}$ attempted to improve the liquid culture system for GA by using Rhizopus sp. MB 46. Their results showed that the productivity of GA was improved by $1 \%$ rice bran, $0.1 \%$ meat extract, and the addition of gauze as a support and was able to develop a GA activity of $0.67 \mathrm{U} / \mathrm{mL}$. For our GA production using a metal-ion regulated liquid medium, 37 of 45 Rhizopus strains tested were superior to $0.67 \mathrm{U} / \mathrm{mL}$. This result shows that the metalion regulated liquid culture method leads to production with a high level of GA activity.

Our culture medium consists of only artificial composition, except for cassava starch. Rhizopus sp. MKU 40 using a metal-ion regulated liquid medium produced a high specific GA activity (21.9 U/mg protein).

The Rhizopus sp. MKU 40 produced little acid or neutral protease. Hayashida and Flor ${ }^{15)}$ mentioned the connection between RSDG and protease coexisting in the same medium by Aspergillus awamori var. kawachi mutants and showed that the GA from the isolated proteaseless mutant had significantly higher RSDG activity than that from a high protease producing mutant. Nishise's ${ }^{14)}$ and Elegado's ${ }^{7)}$ media were contained rice or wheat bran as an inducer of protease production; however, our medium contained no inducers for protease production. It is shown that the GA from metal-ion regulated liquid culture retains a high level of raw starch digesting activity.

The culture supernatant from Rhizopus sp. 
MKU 40 contained $\alpha$-amylase. Ueda ${ }^{1)}$ mentioned that $\alpha$-amylase coexisting in the same medium has an extremely weak activity to digest raw starch; however, $\alpha$-amylase is able to assist the raw starch digestion of GA. Our results followed this report. The ratio of RSDG activity to GA activity in crude enzyme (0.26) was higher than that in purified enzyme $(0.16)$.

The addition of zinc, iron, and magnesium ions to the medium was essential to growth and to the GA production of Rhizopus sp. MKU 40. The GA production was maximized at $3.94 \mathrm{U} /$ $\mathrm{mL}$ in the presence of $75 \mathrm{ppm}$ of calcium, $2 \mathrm{ppm}$ iron ions, $49 \mathrm{ppm}$ magnesium ions, and $0.7 \mathrm{ppm}$ of zinc ions in liquid medium. These results are similar to our previous paper, which investigated by Rhizopus sp. A-11.5) However, the molecular weight of GA from Rhizopus sp. A-11 was $72.4 \mathrm{kDa}$ by SDS-PAGE. ${ }^{6}$ The molecular weight of GA from Rhizopus sp. MKU 40 in this study was $80.4 \mathrm{kDa}$. Since the adsorption rates of both GAs on raw starch were almost $100 \%$ and both strains had very high ratios of RSDG activity to GA activity with $0.24-0.26$, the GAs from Rhizopus sp. MKU 40 and A-11 was classified as near GA-I.

From these results, the metal-ion regulated liquid culture method leads to the production of a high specific activity for RSDG. We achieved substantial improvement of a liquid culture system for GA and RSDG production.

The authors wish to thank Akiko Kobayashi, Yukari Ishida, and Kaori Morimoto for conducting some of the experimental work.

\section{REFERENCES}

1) S. Ueda : J. Jpn. Soc. Starch Sci., 25, 124-131 (1978).

2) T. Takahashi, K. Kato, Y. Ikegami and M. Irie : J. Biochem., 98, 663-671 (1985).

3) S. Hizukuri :J. Jpn. Soc. Starch Sci., 34, 98-105 (1987).

4) T. Takahashi, Y. Tsuchida and M. Irie: J. Biochem., 92, 1623-1633 (1982).

5) Y. Fujio and H. Morita: J. Ferment. Bioeng., 82, 554-557 (1996).

6) H. Morita and Y. Fujio: Starch, 49, 293-296 (1997).

7) F. B. Elegado and Y. Fujio: J. Gen. Appl. Microbiol., 39, 541-546 (1993).
8) G. R. Kingsley and G. Getchell : Clin. Chem., 6, 466-475 (1969).

9) M. M. Bradford: Anal. Biochem., 72, 248-254 (1976).

10) U. K. Laemmli : Nature, 227, 680-685 (1970).

11) M. Kunitz: J. Gen. Physiol., 30, 291-310 (1947).

12) M. L. Anson: J. Gen. Physiol., 22, 79-89 (1938).

13) H. Fuwa: J. Biochem., 41, 583-603 (1954).

14) H. Nishise, A. Fuji, V. Vongsuvanlert and Y. Tani : J. Ferment. Technol., 66, 397-402 (1988).

15) S. Hayashida and P. Q. Flor: Agric. Biol. Chem., 45, 2675-2681 (1981).

(Received January 17, 1998; Accepted November 19, 1998)

金属イオン制御培養法におけるRhizopus sp.

MKU 40 の生澱粉分解性グルコアミラーゼの生産

\section{森田 洋, 水野康平, 松永真由美, 藤尾雄策}

九州大学農学部食糧化学工学科 (812-8581 福岡市 東区箱崎 6-10-1)

液体培地中に添加する金属イオンの種類と濃度を制 御することにより，特定の代謝産物を大量に生産させ る金属イオン制御培養法の確立を目的として，金属イ オンストレス下での微生物の生理的変化を調べた。微 生物としてRhizopus sp. MKU 40 を用い, 菌の生育 とグルコアミラーゼ生産を微生物生理の指標とした。 その結果, 亜鉛, マグネシウム, 鉄イオンは本菌の生 育およびグルコアミラーゼ生産に必須であった。 ま た，カルシウムイオンの添加により，グルコアミラー ゼの生産性はさらに増強した。これらの金属を至適濃 度添加させることにより，グルコアミラーゼ活性を $3.94 \mathrm{U} / \mathrm{mL}$ にまで増強させることができた。ささらに本 酵素の精製は容易で, 硫安沈澱, CM-Sephadex C-50 イオン交換クロマトグラフィーの 2 段階で完了した。

精製後の比活性值は培養液の 4.8 倍に達し, 活性回収 率も $86.0 \%$ と高かった。またSDS-PAGEにより本酵 素の分子量は約 $80.4 \mathrm{kDa}$ と推定された。本菌が生産 するグルコアミラーゼの生澱粉分解能について調べた ところ, 粗酵素では可溶性澱粉分解活性基準で $26 \%$, 精製酵素では $16 \%$ 程度の高い生澱粉分解活性が得ら れた。ささらに培養液中の蛋白質量あたりの比活性值も $21.9 \mathrm{U} / \mathrm{mg}$ protein と高かったことから, 本培養法は 生澱粉分解性グルコアミラーゼの生産に有望であっ た。 